\title{
PRIMEIRO DECENIO DOS CONSELHOS FEDERAL E REGIONAIS DE ENFERMAGEM
}

Os Conselhos Federal e Regionais de Enfermagem reunem, hoje, mais de 156 mil inscritos como pessoas físicas e empresas, como pessoas jurídicas prestadoras de serviços de enfermagem.

Embora quase na adolescência, esses Conselhos podem contar sua história repleta de realizações, de lutas, de conquistas, de trabalho árduo e, por que não dizer, de frustrações. Frustrações, sim e, a nosso ver, inerecem destaque duas delas: a primeira foi a sustação, pelo Ministério do Trabalho , em 7 de junho de 1978, do provisionamento de atendente de enfermagem, visitador sanitário e instrumentador cirúrgico. Esta medida veio dificultar a fiscalização do exercício profissional da enfermagem, uma vez que há predominância de mão-de-obra não qualificada nas instituições de saúde. A segunda é a demora na aprovação do anteprojeto de lei elaborado pelo Conselho Federal de Enfermagem (COFEN), em 1976, que dispõe sobre o exercício profissional da enfermagem e que regulamenta a profissão do Técnico de Enfermagem, em substituição à tão defasada Lei vigente.

Este anteprojeto, encaminhado ao Ministério do Trabalho, encontrou inúmeras barreiras, por parte deste, e também no Ministério da Saúde e no Ministério da Educação e Cultura.

$\mathrm{Na}$ luta para conseguir a substituição da desatualizada legislação vigente, que regulamenta o exercício da Enfermagem no Pais, e, principalmente, em face do aparecimento do Projeto de Lei $\mathrm{n}^{\circ} 2.726 / 80$, prejudicial aos interesses de todos os profissionais da área da saúde, o COFEN publicou, em 1980, "Enfermagem Brasileira em defesa de seus direitos", com o objetivo de mobilizar a classe e orientar suas reivindicações.

Nesta publicação, foi incluido o texto do anteprojeto de lei enviado ao Ministério do Trabalho. Dois Deputados Federais, Mario Hato, do PMDB, e Nilson Gibson, do PDS, na mesma Sessão da Câmara dos Deputados, transformaram o anteprojeto respectivamente nos Projetos de Lei n? 3.427/80 e 3.487/80. Esses dois Projetos foram apensados, e receberam total apoio nas Comissões e no Plenário da Câmara dos 
Deputados. No Senado Federal, o Projeto recebeu o $\mathrm{n}^{9}$ PL 60/82 e também tem encontrado apoio nas diversas Comissões por onde já tramitou. No momento, aguarda para entrar em votação no Plenário do Senado.

O que devem os enfermeiros fazer? Acomodar-se? Vangloriar-se das conquistas alcançadas e esquecer as dificuldades?

Não é este o pensamento da atual Presidente do COFEN, Maria Ivete Ribeiro de Oliveira. Em seu pronunciamento, por ocasião da solenidade comemorativa dos 10 anos dos Conselhos de Enfermagem, declarou: "Os Conselhos se voltam para o futuro e seu desafio, no solene compromisso de vencer com destemor as dificuldades da hora presente, na plena consciência da intima relação que tem o bom fruto com a semente plantada". De fato, a semente plantada nos idos de 1945 , por Zaira Cintra Vidal, então presidente da Associação Brasileira de Enfermeiras Diplomadas, com a indicação de um grupo de trabalho para elaborar um anteprojeto de criação do Conselho de Enfermagem, regada e cultivada por tantas outras idealistas da enfermagem, cresceu e frutificou.

A pequena semente do anteprojeto de lei para a criação dos Conselhos de Enfermagem brotou e tornou-se realidade concreta com a promulgação da Lei $\mathrm{n}^{\circ} 5.905$, em 12 de julho de 1973.

Com a constituição do primeiro Plenário do Conselho Federal e a instalação dos 20 Conselhos Regionais, em 1975, começaram a aparecer os primeiros frutos, dos quais destacamos: elaboração de todo um conjunto de normas, que hoje estão consolidadas na publicação "Documentos Básicos do COFEN"; promulgação dos Códigos de Deontologia de Enfermagem, de Infração e Penalidades, de Processo Ético e de Processo Eleitoral; o cadastramento de todas as categorias de Enfermagem; o estabelecimento da Filosofia e da Política de Trabalho da Instituição; a luta conjunta com entidades de classe de Enfermagem, e com outros Conselhos da área da saúde, que culminou com a assinatura, em novembro de 1980, do Protocolo de Intenções, para defesa dos interesses da profissão; o estudo conjunto COFEN/ABEn, sobre o PREVSAƯDE, e a conseqüente publicação "A Enfermagem no PREVSAƯDE"; a criação do periódico COFEN-Normas e Notícias (COFEN N/N), e dos Boletins Informativos dos Conselhos Regionais, órgãos oficiais de divulgação da Entidade; a aquisição de sede própria para o COFEN e para os Regionais de SP, CE, DF, PA, AM e GO; o estudo conjunto COFEN/ABEn sobre o "Perfil do Enfermeiro"; a pesquisa de âmbito nacional, conforme convênio COFEN/ABEn/INAMPS, para estudo da prática da enfermagem; e, finalmente, os projetos e a execução da fiscalização profissional, com o objetivo de proteger usuários dos serviços de saúde, e de fortalecer as ações de enfermagem.

E hora de consolidar o trabalho até aqui realizado por meio de: 1 . intensificação da fiscalização do exercício profissional e do registro das Empresas, com vistas à responsabilidade técnica;2. mobilização da 
comunidade de Enfermagem para obter a promulgação do Projeto de Lei do exercício profissional, a fim de que as diversas categorias de Enfermagem possam ter condições para bom desempenho profissional e, em especial, para que o Técnico de Enfermagem, cujo curso foi criado pelo MEC, em 1966, possa encontrar na regulamentação o apoio legal de que carece; 3 . apoio à luta dos Sindicatos de Enfermeiros, no que se refere a melhores condições de trabalho, salários e jormadas mais condizentes com a dignidade da profissão, e ampliação do espaço profissional, não apenas a nivel de execução, mas também nos níveis decisórios das instituições de saúde.

Vamos, pois, unir esforços para enfrentar os desafios do futuro, na certeza de que nossas antecessoras cumpriram sua missão com galhardia.

Maria José Schmidt 